\title{
Faktor Faktor Risiko terjadinya Pneumonia pada Stroke Akut di RSUP Dr Hasan Sadikin Bandung
}

\author{
Novi Fatni Muhafidzah"), Sobaryati**), Emmy H Pranggono***), Yusuf Wibisono*), Cep Juli**), Uni

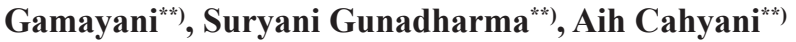 \\ ${ }^{*}$ Resident, Departemen Neurologi Fakultas Kedokteran Universitas Padjadjaran Bandung, ${ }^{* *}$ Konsultan \\ Departemen Neurologi Fakultas Kedokteran Universitas Padjadjaran-RSUP Dr. Hasan Sadikin Bandung, \\ ${ }^{* * *)}$ Konsultan Departemen Ilmu Penyakit Dalam, Fakultas Kedokteran Universitas Padjadjaran Bandung
}

\begin{abstract}
Abstrak
Latar Belakang dan Tujuan: Pneumonia adalah komplikasi non neurologis paling sering pada stroke akut (22\%) yang meningkatkan angka kematian, lama rawat inap dan biaya perawatan. Perlu dilakukan identifikasi faktorfaktor risiko terjadinya pneumonia salah satunya neurogenic pulmonary edema (NPE) agar dapat dilakukan pencegahan dan intervensi dini. Tujuan penelitian ini untuk mengetahui gambaran faktor-faktor risiko terjadinya pneumonia (termasuk NPE) pada pasien stroke akut di RSUP Dr Hasan Sadikin Bandung.

Subjek dan Metode: Deskriptif observasional prospektif, metode consecutive sampling, periode September Oktober 2019, mengumpulkan data primer pasien stroke akut yaitu derajat keparahan stroke, tipe, lokasi dan ukuran lesi stroke, terapi dan tindakan selama perawatan, komorbiditas (termasuk NPE). Pneumonia ditegakkan berdasarkan kriteria Centers for Disease Control and Prevention (CDC), NPE berdasarkan kriteria Davison.

Hasil: 30 orang mengalami pneumonia pada pasien stroke akut (28,30\%). Kejadian pneumonia, lebih sering ditemukan pada pemakaian Nasogastric Tube (NGT) (90\%), disfagia (64,71\%), lokasi infark Sirkulasi Anterior Total (SAT) (61,54\%), ukuran infark besar (61,54\%), GCS 9-12 (50\%) dan NIHSS 16-20 (50\%). NPE didapatkan pada $6,60 \%$ pasien stroke akut, $54,17 \%$ diantaranya menjadi pneumonia.

Simpulan: Kejadian pneumonia pada pasien stroke akut lebih banyak ditemukan pada pemakaian NGT, disfagia, stroke infark lokasi SAT, ukuran infark besar, GCS lebih rendah dan derajat keparahan stroke lebih berat.
\end{abstract}

Kata kunci: Pneumonia, stroke akut, faktor-faktor risiko, neurogenic pulmonary edema (NPE)

JNI $2021 ; 10$ (3): 151-61

\section{Risk Factors of Pneumonia in Acute Stroke at Hasan Sadikin Hospital Bandung}

\begin{abstract}
Background and Objective:Pneumonia is the most common non neurological complications in acute stroke $(22 \%)$ that increase mortality rate, length of stay and hospitalization cost. It is necessary to identified risk factors for pneumonia including neurogenic pulmonary edema (NPE) for better prevention and early intervention. The purpose of this study is to determine risk factors of pneumonia (including NPE) in acute stroke patients at Hasan Sadikin General Hospital Bandung.

Subject and Methods: Prospective observational descriptive study, consecutive sampling method, during September - October 2019. Primary data collected from acute stroke patients such as stroke severity, type, location and size of stroke, treatment during hospitalizataion, comorbidities (including NPE). Pneumonia was diagnosed based on Central for Disease Control Prevention (CDC) criteria, NPE based on Davison criteria.

Results: 30 patients $(28.3 \%)$ with pneumonia in acute stroke patients. Pneumonia were commonly found in NGT insertion (90\%), dysphagia (64,71\%), total anterior circulation infarct (TACI) $(61,54 \%)$, large infarct size (61,54\%), GCS 9-12 (50\%) and NIHSS 16-20 (50\%). NPE only found in 6,60\% acute stroke patients, 57,14\% of them developed pneumonia.

Conclusions: Pneumonia in acute stroke patients is more often found in NGT insertion, dysphagia, TACI location, large infarct size, lower GCS and more severe stroke degree.
\end{abstract}

Key words: Pneumonia, acute stroke, risk factors, neurogenic pulmonary edema (NPE)

JNI $2021 ; 10(3): 151-61$

This article is licensed under a

Creative Commons Attribution-NonCommercial-ShareAlike 4.0 International License.

CNovi FM, Sobaryati, Emmy HP, Yusuf W, Cep J, Uni G, Suryani G, Aih C

(2021) under the CC-BY-NC-SA license 


\section{Pendahuluan}

Stroke merupakan salah satu penyebab kematian tertinggi di Indonesia yaitu sebesar $29,2 \%{ }^{1}$ Penyebab kematian tersering pada pasien stroke adalah karena komplikasi yang diakibatkannya, yaitu sebesar 40\%-96\%. Komplikasi non neurologis yang paling sering terjadi pada stroke fase akut adalah infeksi yaitu pneumonia $(22 \%){ }^{2}$ Angka kejadian pneumonia pada pasien stroke di Indonesia pada tahun 2016 sebesar 22,9\%, sedangkan angka kejadian pneumonia pada pasien stroke akut di RSUP Dr Hasan Sadikin periode 2014-2017 sebesar 29,6\%. ${ }^{3}$

Komplikasi pneumonia pada stroke akut dapat meningkatkan angka mortalitas dan morbiditas, mahalnya biaya perawatan serta pemanjangan lama rawat inap (Length of Stay/LOS). ${ }^{4}$ Gambaran mengenai faktor-faktor risiko terjadinya pneumonia pada pasien stroke akut diperlukan agar dapat melakukan upaya pencegahan dan intervensi dini sehingga luaran klinis lebih baik. Kejadian pneumonia pada stroke akut merupakan gabungan antara mekanisme stroke induced immunodepression syndrome (SIDS) dengan berbagai faktor risiko pada pasien stroke seperti usia tua, jenis kelamin laki-laki, penurunan kesadaran, derajat keparahan stroke yang berat, adanya disfagia, komorbiditas penyakit, tipe, lokasi dan ukuran lesi stroke, serta tindakan dan terapi selama perawatan. ${ }^{5}$ Faktor risiko terjadinya pneumonia pada stroke akut juga terjadi pada brain injury yang berat, mencetuskan overaktivitas simpatis akibat respon inflamasi sistemik (Systemic Inflammatory Response Syndrome) melalui pelepasan katekolamin yang mempengaruhi integritas membran basalis alveolus sehingga terjadi peningkatan tekanan hidrostatik kapiler paru dan terjadi transudasi serta penumpukan cairan di rongga alveolus yang disebut neurogenic pulmonary edema (NPE) ${ }^{6}$ Penumpukan cairan di paru ini merupakan media yang baik untuk pertumbuhan bakteri karena memudahkan kolonisasi kuman di paru. ${ }^{6}$

Gambaran keseluruhan faktor-faktor risiko terjadinya pneumonia pada pasien stroke akut termasuk NPE sebagai salah satu faktor risikonya belum pernah ada yang meneliti baik di Indonesia maupun di RSUP Dr. Hasan Sadikin Bandung. Tujuan dilakukan penelitian ini adalah untuk mengetahui gambaran faktor-faktor risiko terjadinya pneumonia (termasuk NPE) pada pasien stroke akut yang dirawat di RSUP Dr Hasan Sadikin Bandung.

\section{Subjek dan Metode}

Penelitian ini adalah studi deskriptifobservasional prospektif, dengan metode consecutive samping, dengan rumus besar sampel yaitu:

$\mathrm{N}=$ jumlah sampel

$$
\mathrm{N}=\mathrm{Z} \alpha 2 \text {. P. Q }
$$

$\mathrm{d} 2$

$Z \alpha=$ Defiat baku alfa $(1,96)$

$\mathrm{P}=$ Proporsi kategori variabel yang akan diteliti $(22,9 \%=0,229)$

$\mathrm{Q}=1-\mathrm{P}(77,1 \%=0,771)$

$\mathrm{d}=$ presisi $(0,1)$

sehingga

$$
\frac{\mathrm{N}=(1,96) 2 \cdot 0,229 \cdot 0,771}{(0,1)^{2}}
$$

$\mathrm{N}=67,83 \sim 68$

$\mathrm{N}=68$ sampel $+10 \%$ kemungkinan drop out. $=$ 74,8 75 pasien stroke akut.

Alur penelitian adalah sebagai berikut semua pasien stroke akut yang dirawat di Rumah Sakit Dr. Hasan Sadikin Bandung periode September -Oktober 2019 yang memenuhi kriteria inklusi dan eksklusi (106 orang) dilakukan pencatatan data pasien (karakteristik demografi, anamnesa, pemeriksaan fisik neurologis dan pemeriksaan penunjang), faktor-faktor risiko neurologis dan non neurologis untuk terjadinya pneumonia, serta komorbiditas penyakit), kemudian dilihat apakah selama perawatan mengalami pneumonia atau tidak, setelah itu data diolah dan disajikan dalam bentuk tabel untuk mengetahui faktor-faktor risiko manakah yang lebih sering didapatkan pada pasien stroke dengan pneumonia.

Kriteria inklusi pada penelitian ini adalah 
semua pasien stroke akut baik iskemik maupun perdarahan yang ditegakkan dengan pemeriksaan CT scan kepala tanpa kontras, usia $>18$ tahun dan bersedia mengikuti penelitian. Sedangkan kriteria eksklusinya adalah pasien yang meninggal/ pulang paksa sebelum dilakukan pemeriksaan CT scan kepala/rontgen dada, serta pasien dengan diagnosa akhir bukan stroke. Data primer pasien stroke akut diambil menggunakan lembar pengambilan data penelitian yang meliputi karakteristik demografi (usia, jenis kelamin), data faktor-faktor risiko terjadinya pneumonia (skor Glasgow Coma Scale/GCS), National Institutes Health Stroke Scale/NIHSS), disfagia, riwayat stroke, tipe, lokasi dan ukuran lesi stroke, tindakan pemasangan nasogastric tube (NGT), ventilator, pemakaian acid suppressive drugs, posisi supine, komorbiditas penyakit diabetes melitus (DM), atrial fibrilasi, penyakit paru obstruktif kronis/ PPOK, congestive heart failure (CHF), chronic kidney disease (CKD), NPE serta luaran klinis pasien (lama rawat dan kematian/ perbaikan).

Definisi operasional stroke akut pada penelitian ini adalah pasien stroke yang didiagnosa berdasarkan klinis World Health Organization (WHO) dan ditunjang dengan pemeriksaan CT scan kepala tanpa kontras, dimana onset akut pada stroke iskemik 7 hari, stroke perdarahan 14 hari dan stroke perdarahan subarahnoid 21 hari. Pneumonia ditegakkan berdasarkan kriteria Centers for Disease Control and Prevention $(\mathrm{CDC})^{7}$ yang telah diadaptasi oleh Perhimpunan Dokter Paru Indonesia (PDPI), meliputi kriteria mayor (batuk, sputum, riwayat demam $\left(37,8^{\circ} \mathrm{C}\right)$ ), kriteria minor (dyspneu, nyeri pleuritik, tanda konsolidasi paru pada pemeriksaan fisik, leukosit $>12.000 / \mathrm{mm} 3$ ), kriteria radiologis (infiltrat baru disertai dengan satu dari gejala pada kriteria mayor atau dua dari gejala pada kriteria minor). ${ }^{7}$ Komorbiditas penyakit didiagnosa oleh dokter penyakit dalam. NPE ditegakkan berdasarkan kritera diagnosa NPE menurut Davison disertai gejala klinis. ${ }^{6}$ Lokasi dan ukuran lesi stroke iskemik ditetapkan berdasarkan klasifikasi Bamford sedangkan lokasi dan ukuran lesi stroke perdarahan ditetapkan berdasarkan klasifikasi Aguilar dkk, derajat skor intracerebral hemorrhage (ICH) dan modified fischer scale.

\section{Hasil}

Total jumlah subjek penelitian selama periode September-Oktober 2019 adalah 108 pasien stroke akut, yang memenuhi kriteria inklusi sebanyak 106 orang sedangkan eksklusi sebanyak 2 orang. (Tabel 1). Dari 106 orang pasien tersebut terdapat 45 orang dengan gangguan respirasi diantaranya 30 orang $(28,30 \%)$ pneumonia (4 orang diantaranya dengan faktor risiko NPE), 3

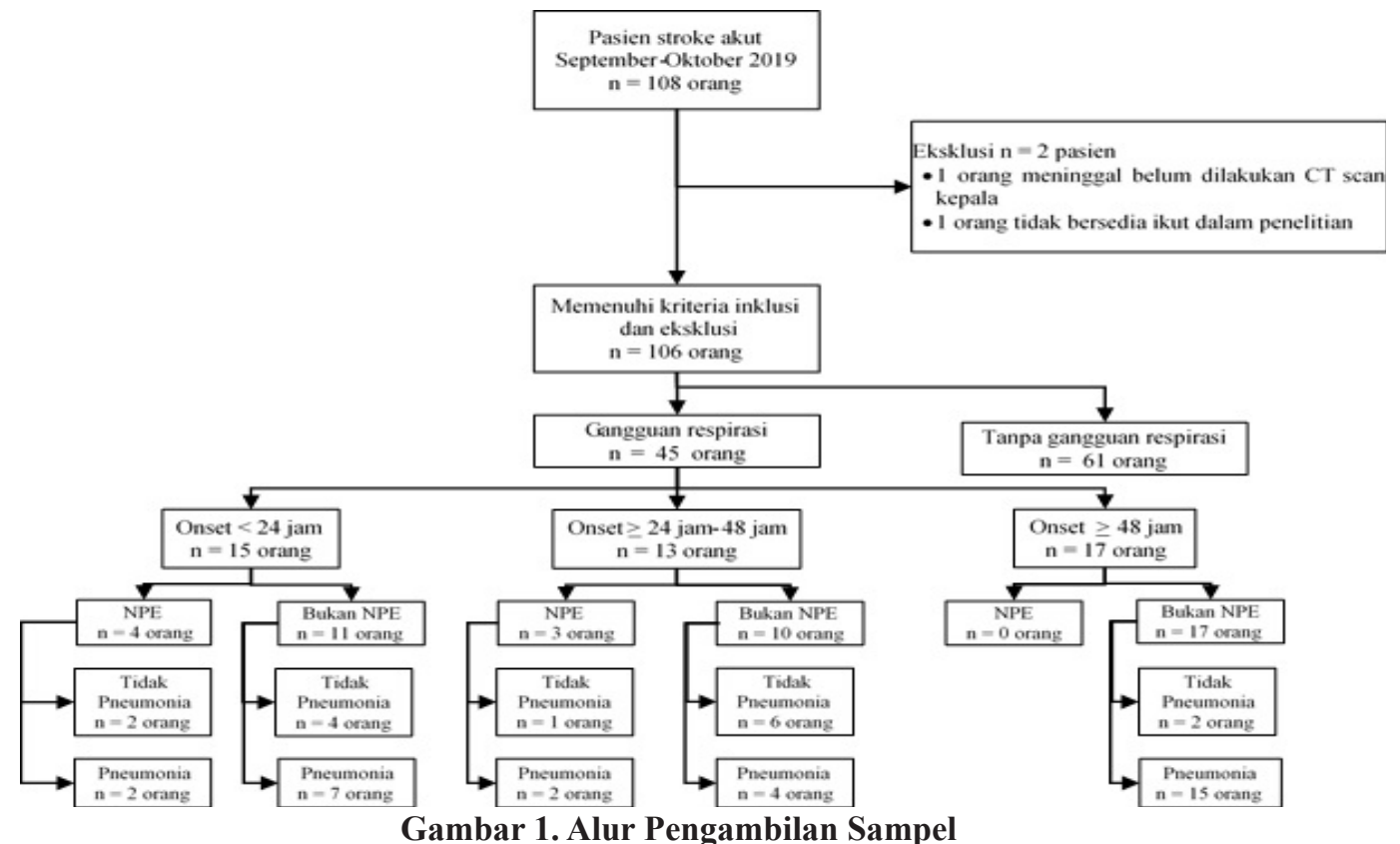

Gambar 1. Alur Pengambilan Sampel 
Tabel 1. Karakteristik Dasar Pasien Stroke Akut

\begin{tabular}{|c|c|c|}
\hline Karakteristik & $\begin{array}{l}\text { Tanpa Pneumonia } \\
\text { (76 orang) } \\
\text { n (\%) }\end{array}$ & $\begin{array}{c}\text { Pneumonia } \\
\text { (30 orang) } \\
\text { n (\%) }\end{array}$ \\
\hline \multicolumn{3}{|c|}{ Usia Klasifikasi WHO } \\
\hline 15-44 tahun & $10(13,16)$ & $3(10)$ \\
\hline 45-59 tahun & $39(51,32)$ & $13(43,33)$ \\
\hline 60-74 tahun & $20(26,32)$ & $10(33,33)$ \\
\hline 75-89 tahun & $7(9,21)$ & $4(13,33)$ \\
\hline Mean $\pm \mathrm{SD}$ & $56,88 \pm 12,66$ & $59 \pm 13,53$ \\
\hline \multicolumn{3}{|l|}{ Jenis Kelamin } \\
\hline Laki-laki & $47(61,84)$ & $21(70)$ \\
\hline Perempuan & $29(38,16)$ & $9(30)$ \\
\hline \multicolumn{3}{|c|}{ Onset sesak nafas } \\
\hline$<24$ jam & $7(9,21)$ & $9(30)$ \\
\hline$>24-48$ jam & $6(7,89)$ & $6(20)$ \\
\hline$>48$ jam & $3(3,95)$ & $15(50)$ \\
\hline
\end{tabular}

Tabel 2a. Faktor-Faktor Risiko terjadinya Pneumonia pada Pasien Stroke Akut

\begin{tabular}{|c|c|c|}
\hline Faktor Risiko & $\begin{array}{c}\text { Tanpa Pneumonia } \\
\text { (76 orang) } \\
\text { n (\%) }\end{array}$ & $\begin{array}{c}\text { Pneumonia } \\
\text { (30 orang) } \\
\text { n (\%) }\end{array}$ \\
\hline \multicolumn{3}{|c|}{ Defisit Neurologis \& Derajat Keparahan Stroke } \\
\hline \multicolumn{3}{|c|}{ Glasgow Coma Scale (GCS) } \\
\hline Ringan GCS 13-15 & $53(69,74)$ & $6(20)$ \\
\hline Sedang GCS 9-12 & $20(26,32)$ & $15(50)$ \\
\hline Berat GCS 3-8 & $3(3,95)$ & $9(30)$ \\
\hline Median (IQR) & $14(6-15)$ & $9(7-15)$ \\
\hline \multicolumn{3}{|l|}{ NIHSS } \\
\hline 1-4 Mild & $18(23,68)$ & $0(0)$ \\
\hline 5- 15 Moderate & $52(68,42)$ & $14(46,67$ \\
\hline 16-20 Severe & $6(7,89)$ & $15(50)$ \\
\hline 21-42 Very severe & $0(0)$ & $1(3,33)$ \\
\hline Median (IQR) & $9(1-19)$ & $16(8-21)$ \\
\hline \multicolumn{3}{|l|}{ Disfagia } \\
\hline Ya & $16(23,19)$ & $11(64,71)$ \\
\hline Tidak & $53(76,81)$ & $6(35,29)$ \\
\hline \multicolumn{3}{|c|}{ Riwayat stroke sebelumnya } \\
\hline $\mathrm{Ya}$ & $17(22,37)$ & $13(43,33)$ \\
\hline Tidak & $59(77,63)$ & $17(56,67)$ \\
\hline
\end{tabular}


Tabel 2b. Faktor-Faktor Risiko terjadinya Pneumonia pada Pasien Stroke Akut

\begin{tabular}{|c|c|c|}
\hline Faktor Risiko & $\begin{array}{c}\text { Tanpa Pneumonia } \\
\text { (76 orang) } \\
\text { n (\%) }\end{array}$ & $\begin{array}{c}\text { Pneumonia } \\
\text { (30 orang) } \\
\text { n }(\%)\end{array}$ \\
\hline \multicolumn{3}{|c|}{ Tipe, Lokasi \& Ukuran lesi Stroke } \\
\hline \multicolumn{3}{|l|}{ Tipe stroke } \\
\hline Stroke Iskemik & $44(57,89)$ & $13(43,33)$ \\
\hline Stroke Perdarahan & $32(42,11)$ & $17(56,67)$ \\
\hline \multicolumn{3}{|l|}{ Lokasi stroke perdarahan } \\
\hline Deep ICH & $14(63,64)$ & $10(71,43)$ \\
\hline Lobar ICH & $5(22,73)$ & $3(21,43)$ \\
\hline Infratentorial & $3(13,64)$ & $1(7,14)$ \\
\hline \multicolumn{3}{|l|}{ Skor ICH } \\
\hline Skor ICH $<2$ & $20(90,91)$ & $8(57,14)$ \\
\hline Skor $\mathrm{ICH}>2$ & $2(9,09)$ & $6(42,86)$ \\
\hline \multicolumn{3}{|l|}{ Volume perdarahan } \\
\hline$<30 \mathrm{cc}$ & $18(23,68)$ & $7(50)$ \\
\hline$>30 \mathrm{cc}$ & $4(5,26)$ & $7(50)$ \\
\hline Median (Range) & $13,62(2,13-82,5)$ & $30,67(5,2-122,72)$ \\
\hline \multicolumn{3}{|l|}{ Skala modified fischer } \\
\hline Modified Fischer grade $<2$ & $7(70)$ & $0(0)$ \\
\hline Modified Fischer grade $>2$ & $3(30)$ & $3(100)$ \\
\hline \multicolumn{3}{|l|}{ Lokasi stroke iskemik } \\
\hline $\begin{array}{l}\text { Sirkulasi Anterior Total } \\
\text { (SAT) }\end{array}$ & $6(13,64)$ & $8(61,54)$ \\
\hline $\begin{array}{l}\text { Sirkulasi Anterior Parsial } \\
\text { (SAP) }\end{array}$ & $16(36,36)$ & $2(15,38)$ \\
\hline Lakunar & $20(45,45)$ & $2(15,38)$ \\
\hline Sirkulasi Posterior (SP) & $2(4,55)$ & $1(7,69)$ \\
\hline \multicolumn{3}{|l|}{ Ukuran lesi stroke iskemik } \\
\hline Lesi kecil & $20(45,45)$ & $3(23,08)$ \\
\hline Lesi sedang & $16(36,36)$ & $2(15,38)$ \\
\hline Lesi besar & $8(18,18)$ & $8(61,54)$ \\
\hline \multicolumn{3}{|l|}{ Komordibitas Penyakit } \\
\hline \multicolumn{3}{|l|}{ Hipertensi (HT) } \\
\hline HT stage 1 & $14(18,42)$ & $9(30)$ \\
\hline HT stage 2 & $41(53,95)$ & $13(43,33)$ \\
\hline Krisis Hipertensi & $11(14,47)$ & $6(20)$ \\
\hline Tidak Hipertensi & $10(13,16)$ & $2(6,67)$ \\
\hline \multicolumn{3}{|l|}{ Diabetes Melitus } \\
\hline $\mathrm{Ya}$ & $16(21,05)$ & $8(26,67)$ \\
\hline Tidak & $60(78,95)$ & $22(73,33)$ \\
\hline
\end{tabular}

Keterangan: Data kategorik disajikan dalam frekuensi dan persentase, sedangkan data numerik disajikan dalam rata-rata, nilai tengah dan nilai rentang. 
Tabel 2c. Faktor-Faktor Risiko terjadinya Pneumonia pada Pasien Stroke Akut

\begin{tabular}{|c|c|c|}
\hline Faktor Risiko & $\begin{array}{c}\text { Tanpa Pneumonia } \\
\text { (76 orang) } \\
\text { n (\%) }\end{array}$ & $\begin{array}{c}\text { Pneumonia } \\
\text { (30 orang) } \\
\text { n (\%) }\end{array}$ \\
\hline \multicolumn{3}{|l|}{ Atrial Fibrilasi (AF) } \\
\hline $\begin{array}{l}\text { AF NVR (Normo Ventricular } \\
\text { Response) }\end{array}$ & $2(2,63)$ & $2(6,67)$ \\
\hline $\begin{array}{l}\text { AF RVR (Rapid Ventricular } \\
\text { Response) }\end{array}$ & $2(2,63)$ & $2(6,67)$ \\
\hline Tidak & $72(94,74)$ & $26(86,67)$ \\
\hline \multicolumn{3}{|l|}{ Congestive Heart Failure (CHF) } \\
\hline $\mathrm{Ya}$ & $5(6,58)$ & $6(20)$ \\
\hline Tidak & $71(93,42)$ & $24(80)$ \\
\hline \multicolumn{3}{|l|}{$\begin{array}{l}\text { PPOK (Penyakit Paru Obstruk } \\
\text { tif Kronis) }\end{array}$} \\
\hline Ya & $3(3,95)$ & $4(13,33)$ \\
\hline Tidak & $73(96,05)$ & $26(86,67)$ \\
\hline \multicolumn{3}{|l|}{ Chronic Kidney Disease (CKD) } \\
\hline Ya & $4(5,26)$ & $3(10)$ \\
\hline Tidak & $72(94,74)$ & $27(90)$ \\
\hline \multicolumn{3}{|l|}{ Neurogenic Pulmonary Edema } \\
\hline \multicolumn{3}{|l|}{ NPE } \\
\hline Ya & $3(3,95)$ & $4(13,33)$ \\
\hline Tidak & $73(96,05)$ & $26(86,67)$ \\
\hline \multicolumn{3}{|l|}{ Kebiasaan Pasien } \\
\hline \multicolumn{3}{|l|}{ Kebiasaan Merokok } \\
\hline Merokok & $47(61,84)$ & $18(60)$ \\
\hline Tidak Merokok & $29(38,16)$ & $12(40)$ \\
\hline
\end{tabular}

orang $(6,60 \%)$ NPE tanpa pneumonia, serta 12 orang pasien dengan gangguan respirasi penyebab lain. Karakteristik dasar pasien stroke dengan pneumonia dibandingkan pasien stroke tanpa pneumonia (tabel 1) yaitu pada pasien pneumonia cenderung lebih sering terjadi pada rentang usia 45-59 tahun (43,33\%), jenis kelamin laki-laki (70\%) dan onset sesak nafas $>48$ jam $(50 \%)$.

Pada penelitian ini ditemukan faktor-faktor risiko pada pasien stroke dengan pneumonia dibandingkan pasien stroke tanpa pneumonia (tabel 2) yaitu pada pasien pneumonia cenderung lebih banyak terjadi pada skor GCS awal 9-12 $(50 \%)$, NIHSS yang berat (16-20) (50\%), adanya disfagia $(64,71 \%)$, volume perdarahan yang besar (nilai median $30,67 \mathrm{cc}(5,2-122,72 \mathrm{cc})$, lokasi infark di SAT $(61,54 \%)$ serta ukuran infark yang besar $(61,54 \%)$. Data kategorik disajikan dalam frekuensi dan persentase, sedangkan data numerik disajikan dalam rata-rata, nilai tengah dan nilai rentang. Pneumonia pada pasien stroke akut juga cenderung lebih banyak ditemukan pada pasien dengan pemasangan NGT (90\%), sedangkan faktor risiko komorbiditas penyakit (DM, atrial fibrilasi, PPOK, CHF dan CKD) serta NPE lebih besar persentasenya pada pasien stroke dengan pneumonia dibandingkan dengan pasien stroke tanpa pneumonia (tabel 2).

Luaran klinis pasien stroke dengan pneumonia (tabel 4) lebih banyak yang didiagnosa HAP 
Tabel 3. Karakteristik Faktor Risiko Terapi dan Tindakan selama Perawatan

\begin{tabular}{|c|c|c|}
\hline Faktor Risiko & Tanpa Pneumonia (76 orang) n (\%) & Pneumonia (30 orang) n (\%) \\
\hline \multicolumn{3}{|c|}{ Pemasangan Nasogastric Tube (NGT) } \\
\hline Ya & $37(48,68$ & $27(90)$ \\
\hline Tidak & $39(51,32)$ & $3(10)$ \\
\hline \multicolumn{3}{|c|}{ Ventilasi mekanik } \\
\hline Ya & $2(2,63)$ & $8(26,67)$ \\
\hline Tidak & $74(97,37)$ & $22(73,33)$ \\
\hline \multicolumn{3}{|c|}{ Acid Suppressive Drug } \\
\hline Ya & $42(55,26)$ & $23(76,67)$ \\
\hline Tidak & $34(44,74)$ & $7(23,33)$ \\
\hline \multicolumn{3}{|l|}{ Oral Hygiene } \\
\hline Ya & $10(13,16)$ & $10(33,33)$ \\
\hline Tidak & $66(86,84)$ & $20(66,67)$ \\
\hline \multicolumn{3}{|l|}{ Posisi Kepala } \\
\hline Supine & $21(27,63)$ & $12(40)$ \\
\hline Head Up $30^{\circ}$ & $55(72,37$ & $18(60)$ \\
\hline
\end{tabular}

Data kategorik disajikan dalam frekuensi dan persentase, sedangkan data numerik disajikan dalam ratarata, nilai tengah dan nilai rentang

Tabel 4. Karakteristik Luaran Klinis Pasien Stroke Akut

\begin{tabular}{|c|c|c|}
\hline Faktor Risiko & $\begin{array}{c}\text { Tanpa Pneumonia (76 orang) } \\
\text { n (\%) }\end{array}$ & $\begin{array}{c}\text { Pneumonia (30 orang) } \\
\text { n }(\%)\end{array}$ \\
\hline \multicolumn{3}{|l|}{ Jenis Pneumonia } \\
\hline Community Acquired Pneumonia (CAP) & $0(0)$ & $11(36,67)$ \\
\hline Hospital Acquired Pneumonia (HAP) & $0(0)$ & $16(53,33)$ \\
\hline Ventilator Acquired Pneumonia (VAP) & $0(0)$ & $3(10)$ \\
\hline \multicolumn{3}{|l|}{ Luaran Klinis } \\
\hline Perbaikan & $69(90,79)$ & $14(46,67)$ \\
\hline Meninggal & $7(9,21)$ & $13(43,33)$ \\
\hline Pulang Paksa & $0(0)$ & $3(10)$ \\
\hline \multicolumn{3}{|l|}{ Lama rawat inap } \\
\hline$<7$ hari & $24(31,58)$ & $11(36,67)$ \\
\hline 8-14 hari & $44(57,89)$ & $9(30)$ \\
\hline 15-21 hari & $7(9,21)$ & $9(30)$ \\
\hline$>21$ hari & $1(1,32)$ & $1(3,33)$ \\
\hline Median (Range) & $9(2-28)$ & $10(2-22)$ \\
\hline \multicolumn{3}{|l|}{ Penyebab kematian } \\
\hline Syok sepsis \& Respiratory Failure & $0(0)$ & $4(30,77)$ \\
\hline Respiratory Failure & $0(0)$ & $7(53,85)$ \\
\hline Herniasi & $5(71,43)$ & $2(15,38)$ \\
\hline Rebleeding perdarahan subarahnoid & $1(14,29)$ & $0(0)$ \\
\hline Syok Kardiogenik & $1(14,29)$ & $0(0)$ \\
\hline
\end{tabular}

Keterangan: Data kategorik disajikan dalam frekuensi dan persentase, sedangkan data numerik disajikan dalam nilai tengah dan nilai rentang 
(53,33\%), angka kematian pada pasien stroke dengan pneumonia lebih besar $(43,33 \%)$ dibandingkan dengan pasien stroke tanpa pneumonia $(9,21 \%)$. Penyebab kematian paling sering pada pasien stroke dengan pneumonia disebabkan respiratory failure.

\section{Pembahasan}

Karakteristik pasien stroke dengan pneumonia dibandingkan pasien stroke tanpa pneumonia (tabel 1), yaitu pada pasien pneumonia cenderung lebih sering terjadi pada kelompok usia 45-59 tahun dengan rata-rata usia $59+13,53$. Hal ini sesuai dengan penelitian prosfektif di India ${ }^{8}$ melaporkan rata-rata usia yang lebih muda pada pasien stroke dengan pneumonia nosokomial yaitu $55,1+16,2$ tahun. ${ }^{8}$ Hasil ini berbeda dengan penelitian kohort skor model prediksi post stroke pneumonia (PSP) di Jerman ${ }^{9}$ yang menyatakan bahwa usia tua $>65$ tahun merupakan faktor prediktor terjadinya pneumonia. ${ }^{9}$ Usia tua (terutama $>65$ tahun) merupakan salah satu faktor risiko terjadinya pneumonia pada stroke karena hal ini berkaitan dengan menurunnya reflek protektif seperti batuk dan menelan. ${ }^{9}$ Perbedaan karakteristik usia pada pasien stroke dengan pneumonia ini terjadi karena terdapat pergeseran usia pasien stroke pada usia lebih muda dibandingkan sebelum tahun 2005, dimana proporsi pasien stroke dengan usia dibawah 55 tahun meningkat dari $12,9 \%$ menjadi $18,6 \%$ pada tahun $2005 .{ }^{8}$

Persentase jenis kelamin laki-laki pada pasien stroke dengan pneumonia sebesar 70\% (tabel 1), sedangkan persentase pada penelitian kontrol kasus multisenter di Amerika sebesar 59,5\%. ${ }^{10}$ Pada penelitian kohort skor model prediksi PSP di Jerman ${ }^{9}$ dan penelitian metaanalisis dari 59 $\operatorname{artikel}^{5}$ menyatakan bahwa jenis kelamin laki-laki merupakan salah satu faktor prediktor terjadinya pneumonia pada pasien stroke akut (Odds Ratio/ OR 1,42). ${ }^{5,9}$ Hal ini berkaitan dengan hormon androgen dihidrotestosteron (DHT) merupakan hormon poten pada laki-laki yang memiliki efek memperberat kondisi imunosupresi setelah suatu brain injury karena stroke. ${ }^{9}$ Pada penelitian ini, kejadian pneumonia pada stroke akut cenderung lebih sering terjadi pada pasien dengan skor GCS 9-12 (50\%) (tabel 2), hal ini sesuai dengan penelitian kohort di China ${ }^{11}$ yang menyatakan bahwa semakin rendah GCS maka risiko terjadinya pneumonia semakin besar (OR 3,3 pada GCS <13). ${ }^{11}$ Penurunan kesadaran ditandai dengan skor GCS yang rendah menyebakan penurunan refleks menelan karena terjadi gangguan fungsi spinkter esofagus dan koordinasi yang tidak efektif antara menelan dan bernafas, sehingga meningkatkan risiko aspirasi. ${ }^{11}$ Kejadian pneumonia pada stroke akut juga cenderung lebih banyak terjadi pada skor NIHSS 16-20 (50\%), hal ini sesuai dengan penelitian kohort skor model prediksi PSP di Jerman ${ }^{9}$ yang melaporkan bahwa semakin tinggi skor NIHSS maka risiko terjadinya pneumonia semakin besar (OR 6,47 pada NIHSS 16-20). ${ }^{9}$ Derajat beratnya defisit neurologis (NIHSS) merupakan faktor prediktor pada perubahan dinamik fungsi menelan/ disfagia. Insidensi dan derajat beratnya disfagia dipengaruhi oleh faktor skor NIHSS yang tinggi, lokasi stroke di hemisfer sebelah kiri, dan keterlibatan sistem vertebrobasilar. ${ }^{9}$

Kejadian pneumonia cenderung lebih banyak terjadi pada pasien stroke akut dengan disfagia $(64,71 \%)$ (Tabel 2), hasil ini sesuai dengan penelitian kohort skor model prediksi PSP di Jerman $^{9}$ dan penelitian kohort di China ${ }^{11}$ yang menyatakan bahwa disfagia merupakan prediktor terjadinya pneumonia (OR 2,64). Disfagia berkaitan dengan disfungsi orofaring, dengan ciri lambatnya gerakan hyolaringeal selama fase menelan. ${ }^{9}$ Pada penelitian ini, kejadian stroke ulang pada pasien stroke dengan pneumonia hanya $43,33 \%$, tetapi jika dibandingkan dengan tanpa pneumonia persentase stroke ulang lebih kecil yaitu $22,37 \%$. (Tabel 2). Hasil ini sesuai dengan penelitian kontrol kasus di Australia ${ }^{12}$ dimana persentase riwayat stroke sebelumnya ditemukan sebesar $35,9 \% .^{12}$ Pada penelitian kontrol kasus di Australia dan penelitian metaanalisis dari 59 artikel melaporkan bahwa riwayat stroke sebelumnya meningkatkan risiko terjadinya pneumonia pada pasien stroke (OR 1,03). ${ }^{5,12}$ Stroke ulang berkaitan dengan kesulitan menelan akibat disfagia sehingga resiko terjadinya aspirasi lebih besar. ${ }^{5,12}$ Pasien stroke dengan 
pneumonia cenderung lebih banyak terjadi pada tipe stroke perdarahan $(56,67 \%)$ (Tabel 2), hal ini terjadi karena pada stroke perdarahan, berhubungan dengan penurunan kesadaran yang lebih berat akibat tekanan tinggi intrakranial (TTIK), sehingga respon inflamasi, kerusakan jaringan saraf, serta kondisi imunosupresinya lebih hebat. ${ }^{13}$ Semua pasien dalam penelitian ini dirawat secara konservatif dan tidak dilakukan tindakan operatif.

Pada penelitian ini stroke dengan pneumonia paling sering terjadi di lokasi deep ICH $(71,43 \%)$, volume perdarahan $>30 \mathrm{cc}$ (nilai median 30,67 cc $(5,2-122,72)$ (Tabel 2), hal ini terjadi karena pada stroke perdarahan, berhubungan dengan penurunan kesadaran yang lebih berat akibat tekanan tinggi intrakranial (TTIK), sehingga respon inflamasi, kerusakan jaringan saraf, serta kondisi imunosupresinya lebih hebat. Hasil pada penelitian ini juga sesuai dengan review literatur daribeberapa kasus perdarahan intrakranial ${ }^{13}$ yang melaporkan bahwa paroksismal hiperaktivitas simpatis (sebagai dasar patofisiologi terjadinya imunodepresi pada stroke) lebih banyak terjadi pada stroke perdarahan intraserebral, volume perdarahan $>30 \mathrm{cc}$, skor $\mathrm{ICH}>2$ serta lokasi di subkortikal (deep $I C H) .{ }^{13}$

Penelitian prospektif di Columbia14 melaporkan pneumonia lebih sering terjadi pada perdarahan subarahnoid primer dengan modified fischer scale 3 , sedangkan kematian lebih sering terjadi pada modified fischer scale $4 .{ }^{14}$ Penelitian tersebut sejalan dengan penelitian ini dimana pneumonia lebih sering ditemukan pada stroke perdarahan subarahnoid dengan modified fischer scale $>2 \quad(100 \%)$. Skala fischer berkorelasi dengan tingginya jumlah sitokin inflamasi sehingga menyebabkan kondisi imunosupresi akibat aktivitas simpatis berlebih. ${ }^{14}$ Karakteristik stroke iskemik pada pasien stroke dengan pneumonia cenderung lebih sering terjadi pada lokasi sirkulasi anterior $(76,92 \%)$ dan dengan lesi infark yang besar $(61,54 \%)$. (Tabel 2). Hasil ini sesuai dengan penelitian kontrol kasus di Australia ${ }^{12}$ yang melaporkan pneumonia lebih sering ditemukan pada stroke infark dengan lokasi di sirkulasi anterior, ${ }^{12}$ sejalan dengan penelitian kohort di China ${ }^{11}$ juga menyatakan bahwa sirkulasi anterior merupakan faktor independent yang meningkatkan risiko terjadinya pneumonia (OR 1,38). ${ }^{11}$ Penelitian retrospektif di Korea ${ }^{15}$ menyatakan bahwa infark di sirkulasi anterior berkaitan dengan disfungsi fase oral menelan, ${ }^{15}$ dimana infark dengan lokasi di SAT menunjukkan lesi infark besar yang mengenai struktur insular (pada teritori arteri serebri media), dimana lesi pada insular menyebabkan stimulasi simpatis berlebih sehingga mencetuskan imunodepresi yang lebih hebat. ${ }^{16}$ Penelitian prospektif observasional di Jerman ${ }^{16}$ juga menyatakan bahwa ukuran lesi infark yang besar $(58,33 \%)$ berkorelasi terhadap kejadian pneumonia (OR 3,5 pada ukuran infark yang besar $(>5 \mathrm{~cm})$ atau $>$ $1 / 3$ arteri serebri media). ${ }^{16}$

Pasien stroke dengan pneumonia cenderung lebih banyak datang dengan hipertensi saat onset akut stroke $(90,33 \%)$, diantaranya lebih sering dengan hipertensi stage 2 (Tabel 2). Hasil ini sesuai dengan penelitian kontrol kasus di Australia ${ }^{12}$ dimana persentase hipertensi pada pasien stroke dengan pneumonia sebesar 83,8\%. ${ }^{12}$ Pada penelitian ini persentase hipertensi krisis pada pasien stroke dengan pneumonia lebih besar (20\%) dibandingkan dengan persentase pada pasien stroke tanpa pneumonia $(14,47 \%)$. Derajat beratnya hipertensi menentukan tingkat beratnya aktivitas simpatis sebagai dasar imunodepresi serta meningkatkan risiko terjadinya pneumonia pada pasien stroke. ${ }^{13}$ Pada penelitian ini, faktor risiko NPE ditemukan pada 4 orang (13,33\%) pasien stroke dengan pneumonia, sedangkan dari 7 orang pasien NPE, terdapat 57,14\% yang menjadi pneumonia. (Tabel 2). Hal ini sesuai dengan penelitian retrospektif di China ${ }^{17}$ dan penelitian kontrol kasus multisenter di Amerika, ${ }^{10}$ yang melaporkan bahwa edema paru merupakan faktor prediktor terjadinya komplikasi infeksi pada stroke. ${ }^{17}$ Pada penelitian retrospektif di China $^{17}$ juga menyatakan bahwa pasien dengan skor A2DS2 $>10$ memiliki risiko terjadinya NPE yang berkaitan dengan eksitasi saraf simpatis yang berlebih sehingga menyebabkan peningkatan permeabilitas kapiler paru serta transudasi cairan ke paru. ${ }^{17}$ Pasien stroke dengan pneumonia cenderung lebih banyak terjadi pada 
pasien dengan pemakaian NGT (90\%) (Tabel 3), penelitian kontrol kasus di Australia ${ }^{12}$ menyatakan bahwa pemakaian NGT meningkatkan risiko terjadinya pneumonia (OR 3,14), karena dengan pemakaian NGT menyebabkan migrasi bakteri ke saluran nafas bawah. ${ }^{12}$

Pada penelitian ini Pemberian acid suppressive drugs pada pasien stroke dengan pneumonia lebih besar persentasenya $(76,67 \%)$ dibandingkan pasien stroke tanpa pneumonia $(55,26 \%)$ (Tabel 3). Acid suppressive drugs selain memiliki efek gastroprotektif dengan cara menurunkan sekresi asam lambung, namun tingkat keasaman lambung ini merupakan kondisi yang baik sebagai salah satu barier bakterisidal yang menghalangi masuknya bakteri/kuman yang teraspirasi ke saluran pernafasan. ${ }^{18}$ Penelitian kohort retrospektif di Korea $^{19}$ melaporkan bahwa penggunaan acid suppressive drugs meningkatkan risiko terjadinya pneumonia dengan HR 1,43 pada H2RA (Histamin 2 receptors antagonist) .dan HR 1,85 pada PPI (Proton Pump Inhibitor). ${ }^{19}$

Persentase angka kematian pada pasien stroke dengan pneumonia cenderung lebih tinggi (43,33\%) dibandingkan dengan pasien stroke tanpa pneumonia.(9,21\%) (Tabel 4). Persentase angka kematian pada penelitian ini lebih tinggi dibandingkan penelitian retrospektif di Amerika ${ }^{4}$ dan penelitian kontrol kasus multisenter di Amerika, ${ }^{10}$ dimana pada pasien stroke dengan pneumonia angka kematiannya $20 \%$, sedangkan pada pasien stroke tanpa pneumonia 3,5\% (RR 5,7). ${ }^{4,10}$ Pada penelitian ini, luaran klinis penyebab kematian paling sering pada pasien stroke dengan pneumonia adalah respiratory failure $(84,62 \%)$ (Tabel 4), hal ini kemungkinan terjadi karena penggunaan ventilasi mekanik pada pasien stroke dengan pneumonia hanya $26,67 \%$., disebabkan karena keterbatasan pasien untuk mendapatkan perawatan di Intensive Care Unit (ICU). Lama rawat inap pada pasien stroke dengan pneumonia lebih banyak dengan LOS (Length of Stay) $<7$ hari $(36,67 \%)$ (tabel 4), dengan nilai median 10 hari (2-22), mendekati nilai median pada penelitian prospektif di Denmark ${ }^{20}$ yaitu 11 hari (4-28). ${ }^{20}$ Keterbatasan penelitian ini adalah untuk faktor risiko komorbiditas seperti diabetes melitus
(DM) tidak disertakan kadar glukosa saat onset akut stroke, CHF tidak dibedakan derajatnya berdasarkan functional class I-IV dan CKD tidak dibedakan stadiumnya berdasarkan perhitungan LFG (laju filtrasi glomerulus).

\section{Simpulan}

Kejadian pneumonia pada pasien stroke akut cenderung lebih sering terjadi pada pemakaian NGT, disfagia, lokasi infark di sirkulasi anterior, ukuran infark yang besar, GCS yang lebih rendah dan derajat keparahan stroke yang lebih berat. NPE didapatkan sebesar $6,60 \%$ dari seluruh pasien stroke akut, $57,14 \%$ diantara pasien NPE berkembang menjadi pneumonia.

\section{Daftar Pustaka}

1. Departemen Kesehatan Republik Indonesia. Laporan Nasional Riset Kesehatan Dasar. Jakarta: Pusat Penelitian Pengembangan Kesehatan; 2017.

2. Langhorne P, Stott DJ, Robertson L, MacDonald J, Jones L, McAlpine dkk. Medical complications after stroke. a multicenter study. American Heart Association Journal. 2000.

3. Wandira RD, Amalia L, Fuadi I. Hubungan antara derajat keparahan stroke dengan kejadian Stroke Associated Pneumonia. Neurona 2018; 35(2).

4. Wilson RD. Mortality and cost of pneumonia after stroke for different risk group. Journal of Stroke Cerebrovascular Disease. 2013; 21(1): 61-67.

5. Wasfelt W, Cao Y, Strom JO. Predictors of post stroke fever and infections: a systematic review and meta-analysis. BMC Neurology. 2018.

6. Davison DL, Terek M, Chawla LS. Neurogenic pulmonary edema. Annual Update in Intensive Care and Emergency 
Medicine. Washington, Amerika. 2012.

7. Smith CJ, Kishore AK, Vail A, Chamorro A, Garau J, Hopkins SJ, et al. Diagnosis of stroke associated pneumonia recommendations from the pneumonia in stroke consensus group. Stroke: American Heart Association Journal. 2015; 46. 2335-40

8. Kunhikatta V, Srinivasan M, Thunga G, Rau NR, Nagappa AN. The nosocomial pneumonia mortality prediction (NPMP) model tool to predict mortality in patients with nosocomial pneumonia. Indian Journal of Medical Specialities. 2016; 103: 4.

9. Hoffmann S, Malzahn U, Harms H, Koennecke C, Berger K, Kalic M, et al. Development of a clinical score (A2DS2) to predict pneumonia in acute ischemic stroke. American Heart Association Journal. 2012;43.

10. Lord AS, Langefeld CD, Sekar P, Moomaw CJ, Badjatia N, Vashkevich A dkk. Infection after intracerebral hemorrhage: risk factors and association with outcomes in the ERICH study: National Institites of Health Public Acess. 2014; 45 (2): 3525-42.

11. Ji R, Shen H, Pan Y, Wang P, Liu G, Wang $\mathrm{Y}, \mathrm{dkk}$. A novel risk score to predict 1 year functional outcome after intracerebral hemorrharrge and comparison with existing scores. Critical Care BioMed Central Journal. 2013.

12. Matz K, Seyfang L, Dachenhausen A, Teuschl Y, Tuomilehto J, Brainin M, Collaborators. Collaborators. Post-stroke pneumonia at the stroke unit - a registry based analysis of contributing and protective factors. BMC Neurology. 2016: 107.

13. Gao B, Pollock JA, Hinson HE. Paroxysmal sympathetic hyperactivity in hemispheric intraparenchymal hemorrhage. Annlas of
Clinical and Translational Neurology.2014: 1 (13): 215-19.

14. Lantigua H, Gutierrez SO, Mayer SA. Subarachnoid hemorrhage: who dies and why?. BMC Critical Care. 2015; 19(1): 309.

15. Kim JH, Oh SH, Jeong HJ, Sim YJ, Kim DG, Kim GC. Association between duration of dysphagia recovery and lesion location on magnetic resonance imaging in patients with middle cerebral artery infarction. Ann Rehabilitation Medical Article. 2018; 43(2): 142-148.

16. Minnerup J, Wersching $\mathrm{H}$, Browinkel B, Dziewas R, Heuschmann PU, Nabavi D, dkk. The impact of lesion location and lesion size on post stroke infection frequency: HAL archives ouvertes. Munchen, Jerman. 2011.

17. Li Y, Zhang Y, Ma L, Niu X, Chang J. Risk of stroke associated pneumonia during hospitalization: predictive ability of combined A2DS2 and hyperglycemia. BMC Neurology. 2019; 19: 298.

18. Ho SW, Hsieh MJ, Yang SF, Yeh YT, Wang $\mathrm{YH}$, Yeh CB. Risk of stroke associated pneumonia with acid suppressive drugs. A population based cohort study. Medicine Observasional Study. 2015; 94(29)

19. Song TJ, Kim J. Risk of post stroke pneumonia with proton pump inhibitors, $\mathrm{H} 2$ receptors antagonists and mucoprotective agents: a retrospective nationwide cohort study. Plos One. 2019; 14(5).

20. Ingeman A, Andersen G, Hundborg HH, Svendsen ML, Johnsen SP. In hospital medical complications, length of stay and mortality among stroke unit patients. American Heart Association. 2011; 42(11): 3214-8. 